\title{
Motherhood after cancer: fertility and utilisation of fertility-preservation methods
}

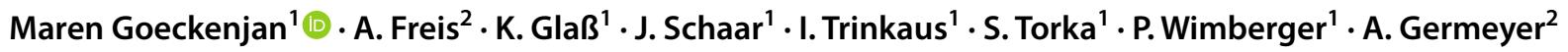

Received: 18 November 2019 / Accepted: 25 April 2020 / Published online: 6 May 2020

(c) The Author(s) 2020

\begin{abstract}
Purpose Due to modern and individualised treatments, women at reproductive age have a high survival rate after cancer therapy. What are pregnancy and birth rates of women after cancer and how often do they use cryopreserved ovarian tissue or gametes?

Methods From 2007 to 2015, 162 women aged $26.7 \pm 6.9$ years were counselled for fertility preservation at a single University Fertility Centre. A questionnaire study was performed in average 3 and 6 years after the diagnosis of cancer. The women were asked about their fertility, partnership, family planning, and pregnancy history. 72 women (51\%) answered a written questionnaire in 2016. 59 women were reached again by phone in 2019 (82\%).

Results The preferred method of fertility preservation was ovarian tissue cryopreservation $(n=36,50 \%)$; none of the women had ovarian hyperstimulation in order to cryopreserve oocytes. About 3 years after treatment, 37 women of 72 women (51\%) of the women with a mean age of 29.9 years had a strong wish to conceive. 21/72 (29\%) had actively tried to conceive after successful cancer treatment; eight women $(11 \%)$ were already pregnant or had children. Six years after cancer diagnosis $16 / 59$ (27\%) women had ongoing anticancer treatment. 12/59 (20\%) were pregnant or had children, while 39\% (23/59) had no menstrual cycle. Only one woman used her cryopreserved ovarian tissue, but did not become pregnant.

Conclusion After cancer and gonadotoxic treatment, women's desire to have a child is substantial. In this study, the rate of spontaneous pregnancies and births was $20 \% 6$ years after gonadotoxic therapies. Not every woman, however, has the opportunity to conceive: factors impairing fertility include ongoing cancer treatment or persistent disease, no partner, no menstrual cycle, as well as other reasons for infertility.
\end{abstract}

Keywords Fertility preservation $\cdot$ Cancer $\cdot$ Ovarian cryopreservation $\cdot$ GnRH agonists $\cdot$ Follow-up

\section{Introduction}

Today's procedures for counselling women with newly diagnosed cancer for fertility preservation are fairly standardised. Due to high survival rates and high quality of life after cancer, women should be given the opportunity to plan motherhood after cancer actively. Methods to preserve fertility in spite of gonadotoxic treatments are well established and available nationwide in Germany. Since the foundation

Maren Goeckenjan

maren.goeckenjan@uniklinikum-dresden.de

1 Department for Gynaecology and Obstetrics, Technische Universität Dresden, University Hospital, Dresden, Germany

2 Department for Gynaecological Endocrinology and Reproductive Medicine, University Hospital of Heidelberg, Heidelberg, Germany of a network on fertility preservation in German-speaking countries, FertiPROTEKT e.V. in 2006, more than 130 centres are counselling women with planned gonadotoxic therapies in cooperation with oncologic medical centres. The network defines objectives for counselling and options for fertility preservation: Patients of reproductive age should be advised about their potential decline in fertility due to the gonadotoxic treatment before its initiation. Effective fertility preservation methods should be discussed and offered [1]. In spite of these efforts to standardise the procedures, the use of fertility-preservation methods differs from centre to centre and regionally.

The registered data of the participating centres show that through 2013, more than 5000 women were counselled and more than 4000 received fertility protective treatments [2]. These treatments include medical therapy with ovarian suppression via gonadotropin-releasing hormone $(\mathrm{GnRH})$ 
agonists, cryopreservation of oocytes after controlled ovarian hyperstimulation, and cryopreservation of ovarian tissue. In many cases, more than one treatment for fertility preservation was used.

Since 2017, German national guidelines with standardised recommendations have been available [3]. International practical recommendations have also been published [4]. Table 1 outlines the currently recommended treatment procedures for women of reproductive age with the most frequent cancer diagnoses. At the time of the study, the methods of fertility preservation were not covered by the national health insurance companies. The costs for controlled ovarian hyperstimulation and aspiration of oocytes as well as cryopreservation of unfertilized or fertilised oocytes for some years were calculated with approximately $1500 €$ for medication, $1500 €$ for aspiration of oocytes, and storage of oocytes (300-400 € per year) [1]. The costs for ovarian tissue cryopreservation were calculated with approximately $1000 €$ for laparoscopic surgery, and shipping, tissue preparation, and storage with $300-400 €$ per year.

Throughout the individual decision-making progress, each woman is given information about the prognosis of her disease, the planned treatment, and its impact on fertility. If a high risk for infertility is suspected and/or the woman has a strong wish to bear her own child, fertility-preservation methods are recommended. The final decision is highly individual and made after an intensive counselling including ethical implications [5]. The interdisciplinary coordination of fertility-preservation methods and oncological treatment, the confrontation of the patient with a possibly life-threatening diagnosis, and the necessity of reaching a decision in a short time create a special burden for the counselling. In addition to these aspects and the financial burden, medical risks must be calculated against the possible benefits of the treatment.

At the University Fertility Centre in Dresden, the counselling of female cancer patients and women with autoimmune disease prior to gonadotoxic treatments has been documented in a local registry since 2007 . Recommended fertility preservation options included all established treatments, including GnRH agonists, ovarian cryopreservation, and cryopreservation of oocytes. The low utilisation rate of hormonal stimulation and cryopreservation of oocytes in the Fertility Centre in Dresden at the study period was due to the high costs of this method and the longer time required compared to ovarian tissue cryopreservation. This may change in the future as the German government recently proclaimed that the costs of cryopreservation of gametes will be covered by the national health insurance. The first birth of a child conceived after autotransplantation of cryopreserved ovarian tissue took place in Dresden [6]. As this novel option for fertility preservation was elaborately discussed and presented in the regional media, cryopreservation of ovarian tissue was the preferred fertility preservation method to be chosen in the counselling process at the University Fertility Centre in Dresden at the time of the study. Current data after autotransplantation of ovarian tissue show that the ovaries resume function in about $80-85 \%$ of women and that pregnancies can be achieved spontaneously [7]. The cryopreservations and autotransplantations were performed in cooperation with the University Hospital of Erlangen.

Follow-up data after using fertility-preservation methods are still sparse. The first major study of long-term follow-up after fertility preservation was published only recently [8]. The data presented in this article show a follow-up after fertility preservation counselling in a single fertility centre in Germany.

\section{Material and methods}

The data of 162 women counselled for fertility preservation between January 2007 and December 2015 at the University Fertility Centre in Dresden were collected in a registry. In 2016, a prospective questionnaire follow-up study was initiated in cooperation with the University Hospital of Heidelberg. The written questionnaire was developed by A. Germeyer and is not validated up to date.

The written questionnaire has 37 items, which include the following topics:

- eight questions: person and disease;

- six questions: family, partnership, and family planning;

- six questions: biological fertility, menstrual cycle, contraception, and hormonal replacement therapy;

- nine questions: reproduction, fertility, and infertility;

- four questions: counselling for fertility preservation; and

- four questions: pregnancies before and after the diagnosis of cancer.

The study protocol was approved by the local ethics committee (EK 314072015). Inclusion criteria were: documented counselling for fertility preservation, age $>18$ years, and written informed consent to the study protocol. The first follow-up was performed via postal mailing. The return rate of the paper questionnaire was $51 \%$ in 2016 . The studyinclusion flowchart of the study is shown in Fig. 1. A second follow-up survey was conducted by telephone in 2019; at that time, 59 of 72 women were reached again (82\%). Seven questions regarding the patients' general health, possible ongoing cancer treatment, current or past pregnancies and births, since fertility preservation counselling, utilisation of cryopreserved material, partnership, and infertility were asked by two medical doctors in a standardised verbal interview.

The characteristics of the women counselled and treated with the methods of fertility preservation in the fertility 


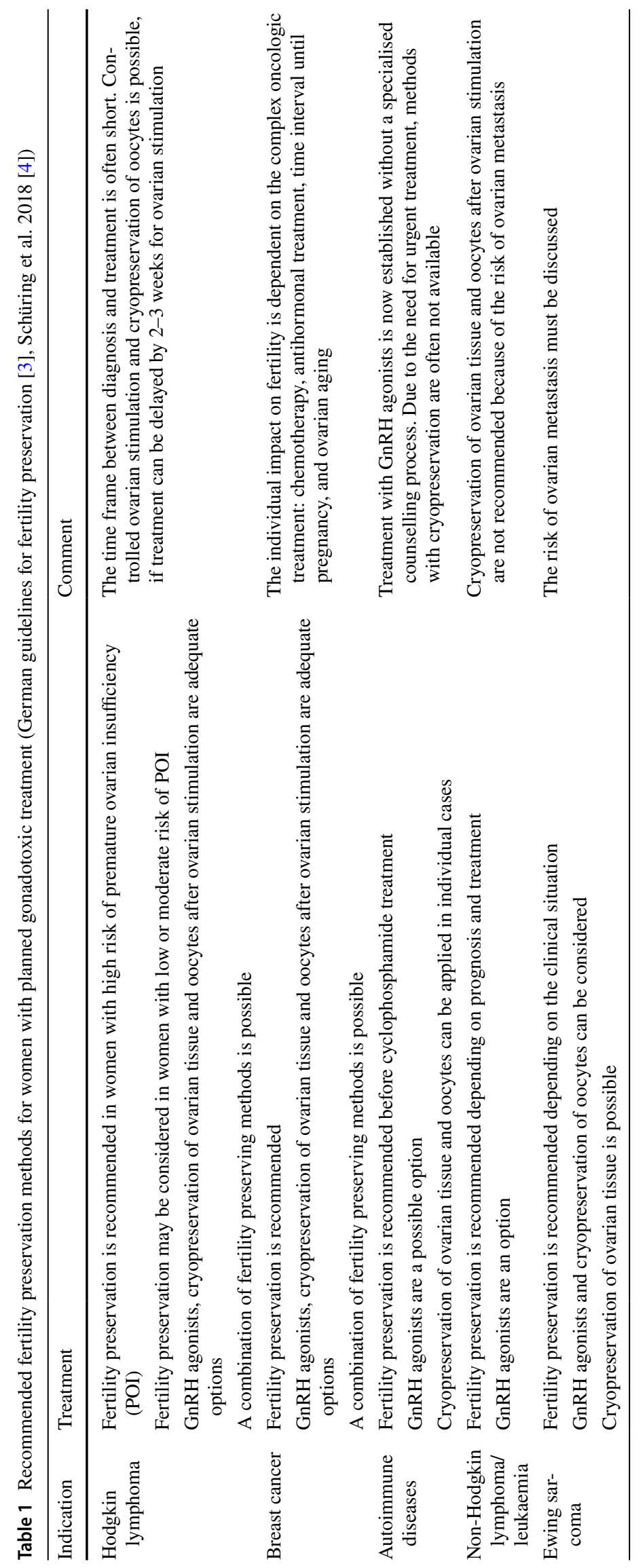




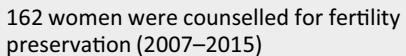

141 women were reached via mail

10 women were identified as dead, four women were $<18$ years old, four women refused consent, three women had no known address

72 women returned the written questionnaire in $2016(51.1 \%)$

59 of 72 women took part in the telephone survey in $2019(81.9 \%)$

Fig. 1 Flowchart of study participants

centre are shown in Table 2. This table indicates that the study group does not differ statistically from all women who were counselled for fertility preservation in the FertiPROTEKT network e.V.

Differences in study groups were compared using Student's $t$ tests and Mann-Whitney $U$ test as appropriate. $p<0.05$ was considered statistically significant. SPSS-V 25.0 was used.

\section{Results}

\section{Results of the written questionnaire, on average 3.1 years after diagnosis}

Of the 162 patients who were counselled for fertility preservation in 2007-2015, ten women were known to have died within 3 years $(6.2 \%) .141$ patients could be contacted by mail, and 72 answered the questionnaire and sent it back, resulting in a response rate of more than $51 \%$. The median latency between the diagnosis of cancer and the questionnaire study was $3.1 \pm 2.2$ years.

The study group generally did not differ from the group of all counselled patients in the same fertility centre within that time frame (Table 2). The data were also compared to the group of women counselled and documented by the FertiPROTEKT network e.V. [1]. Only the group of women with autoimmune diseases was significantly smaller in the study group than the group of all women counselled. This difference may be explained by the special situation of women with benign diseases.

Table 2 Characterisation of study group $(n=72)$ compared to group of counselled women for fertility preservation $(n=162)$ at the time of the questionnaire mailing and rounded data of the FertiPROTEKT network from 2007-2015 [1]

\begin{tabular}{|c|c|c|c|c|}
\hline & $\begin{array}{l}\text { All women counselled for fer- } \\
\text { tility preservation } 2007-2015\end{array}$ & $\begin{array}{l}\text { Study group of women } \\
\text { (answered questionnaire) in } \\
2016\end{array}$ & $\begin{array}{l}\text { Statistical } \\
\text { analysis ( } p \\
\text { value) }\end{array}$ & $\begin{array}{l}\text { Data of the 'Ferti- } \\
\text { PROTEKT' network } \\
\text { 2007-2015 }\end{array}$ \\
\hline Number of women & 162 & 72 & - & $\approx 7150$ \\
\hline $\begin{array}{l}\text { Mean age in years at counselling /diag- } \\
\text { nosis of cancer }\end{array}$ & $26.7 \pm 6.9(6-40)$ & $27.1 \pm 6.3(15-39)$ & 0.689 & 28 \\
\hline $\begin{array}{l}\text { Mean age in years at questionnaire study } \\
(8 / 2016)\end{array}$ & $30.6 \pm 7.2(8-48)$ & $30.4 \pm 6.4(17-44)$ & 0.807 & - \\
\hline \multirow{2}{*}{$\begin{array}{l}\text { Time interval between counselling and } \\
\text { time of contact (sent and/or answered } \\
\text { questionnaire) }\end{array}$} & $3.8 \pm 2.4(1-9)$ & $3.1 \pm 2.2(1-9)$ & 0.064 & - \\
\hline & In $\%(n=)$ & In $\%(n=)$ & $\begin{array}{l}\text { Statistical } \\
\text { analysis ( } p \\
\text { value) }\end{array}$ & In $\%$ \\
\hline \multicolumn{5}{|l|}{ Most frequent diagnoses } \\
\hline Breast cancer & $35.2(57)$ & $37.5(27)$ & 0.735 & 37 \\
\hline Hodgkin lymphoma & $26.5(43)$ & $36.1(26)$ & 0.154 & 26 (incl. NHL) \\
\hline Autoimmune diseases & $9.3(15)$ & $1.4(1)$ & 0.004 & 7 \\
\hline Non-Hodgkin lymphoma & $7.4(12)$ & $8.3(6)$ & 0.807 & Not determined \\
\hline Leukaemia & $5.6(9)$ & $6.9(5)$ & 0.681 & 5 \\
\hline Ewing sarcoma & $3.1(5)$ & $4.2(3)$ & 0.676 & Not determined \\
\hline \multicolumn{5}{|l|}{ Fertility preservation methods ${ }^{\mathrm{a}}$} \\
\hline GnRH & $58.0(94)$ & $62.5(45)$ & 0.552 & 47 \\
\hline Cryopreservation of ovarian tissue & $40.1(65)$ & $50.0(36)$ & 0.161 & 33 \\
\hline Cryopreservation of oocytes & $1.9(3)$ & 0 & 0.083 & 17 \\
\hline Transposition of ovaries & $0.6(1)$ & $1.4(1)$ & 0.556 & 2 \\
\hline
\end{tabular}

${ }^{a}$ Multiple treatment possible, most often GnRH agonists in combination with cryopreservation of ovarian tissue 
These patients usually decide to use ovarian downregulation with GnRH agonist rather than utilising cryopreservation methods.

Figure 2 shows the fertility preservation treatment utilised by the women in the questionnaire study. $22.2 \%$ of the women (16/72) had decided not to have any fertility preservation treatment, while every second woman underwent ovarian cryopreservation (36/72). Almost every third woman in the study group (23/72) combined the medical treatment of a GnRH agonist with the cryopreservation of ovarian tissue.

As part of the questionnaire, women were asked about their general wish to have a child. Table 3 shows the results of the entire study group and subgroups. Women who decided to have ovarian cryopreservation declared 3 years later a stronger wish for their own child; however, this difference was not significant $(p=0.101)$.

Twenty-one women had already tried to conceive (29\%). Of these, eight women became pregnant spontaneously, while 13 women stated that in spite of unprotected sexual intercourse, no pregnancy occurred.
$57 / 72$ women were in a stable partnership (79\%); 12 of these women $(17 \%)$ had a new partnership after cancer. 55/72 women had had no examination of their fertility status after cancer treatment at the time of answering the questionnaire. 7/15 women with fertility check-ups had been given a diagnosis of infertility after gynaecological and/or andrological examinations (47\%). Two women had already undergone infertility treatment with artificial reproductive technologies, but no pregnancy occurred. Two women did not respond to the questions about their fertility status.

Four women reported having had a total of five children after their diagnosis of cancer; in addition, four women were pregnant at the time of the questionnaire. The data of the 8/72 women are depicted in Table 4. All women who were pregnant or already had a child were at least 3 years postcancer diagnosis (6 years on average). The age at diagnosis of cancer ranged from 20 to 29 years. Six of the eight women had ovarian tissue cryopreserved, but had not used it for autotransplantation. All pregnancies occurred spontaneously without infertility treatment or use of cryopreserved tissue.
Fig. 2 Fertility preservation decisions by number and percentage of women in the questionnaire study $(n=72)$

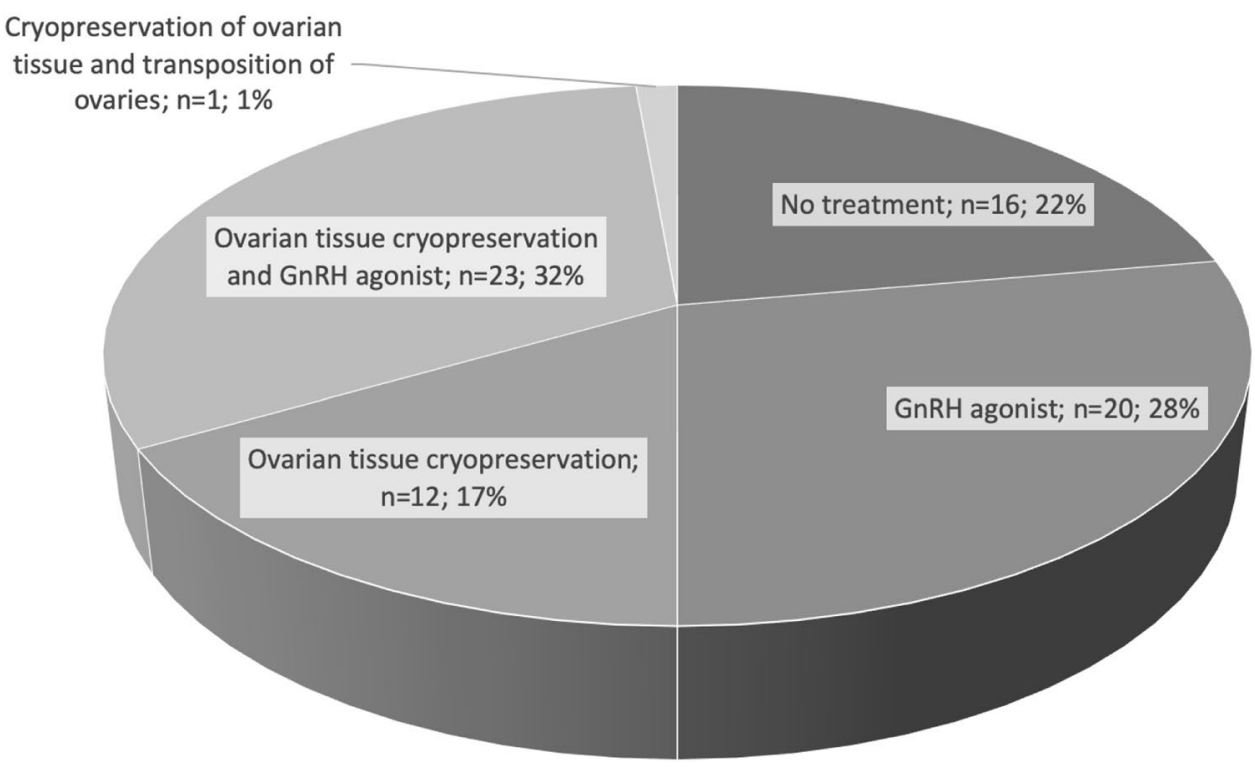

Table 3 Intensity of the desire to have a child three years after counselling in the study group, as well as in the subgroups of women, who underwent invasive fertility preservation versus women, who only used GnRH agonist or no treatment: statistical analysis of differences between the two subgroups $(n=72)$

\begin{tabular}{lllll}
\hline $\begin{array}{l}\text { Intensity of desire to } \\
\text { have a child }\end{array}$ & All women $(n=72)$ & $\begin{array}{l}\text { Women after cryopreservation } \\
\text { of the ovary }(n=36)\end{array}$ & $\begin{array}{l}\text { Women with GnRH agonists or no treat- } \\
\text { ment for fertility preservation }(n=36)\end{array}$ & $\begin{array}{c}p \text { value (Mann- } \\
\text { Whitney } U \\
\text { test) }\end{array}$ \\
\hline None & $8(11.1 \%)$ & $2(5.6 \%)$ & $6(16.7 \%)$ & $0.136($ n.s.) \\
Weak & $17(23.6 \%)$ & $7(19.4 \%)$ & $10(27.8 \%)$ & 0.408 (n.s.) \\
Median & $8(11.1 \%)$ & $5(13.9 \%)$ & $3(8.3 \%)$ & $0.456($ n.s.) \\
Strong & $37(51.4 \%)$ & $22(61.1 \%)$ & $15(41.7 \%)$ & 0.101 (n.s.) \\
No response & $2(2.8 \%)$ & 0 & $2(5.6 \%)$ & 0.154 (n.s.) \\
\hline
\end{tabular}


Table 4 Clinical data of the eight women with pregnancies until their responses to the written questionnaire (median age at pregnancy 29 years)

\begin{tabular}{|c|c|c|c|c|c|c|c|}
\hline & Pregnancy & $\begin{array}{l}\text { Cancer, anticancer } \\
\text { therapy }\end{array}$ & $\begin{array}{l}\text { Cryo- } \\
\text { preserva- } \\
\text { tion }\end{array}$ & $\begin{array}{l}\text { GnRH } \\
\text { ago- } \\
\text { nists }\end{array}$ & $\begin{array}{l}\text { Age at diagnosis } \\
\text { (age at pregnancy) } \\
\text { in years }\end{array}$ & $\begin{array}{l}\text { Interval to preg- } \\
\text { nancy (years since } \\
\text { diagnosis) }\end{array}$ & Comments \\
\hline $1 \mathrm{BK}$ & $\begin{array}{l}\text { Birth of a healthy } \\
\text { child }\end{array}$ & $\begin{array}{l}\text { Breast cancer (Triple } \\
\text { negative pT2, pN1a } \\
{[1 / 11 \mathrm{LK}], \mathrm{L} 0,} \\
\text { V0, G3) } 4 \times \mathrm{EC}, \\
\text { Docetaxel }\end{array}$ & + & - & $23(27)$ & 4 & No utilisation of tissue \\
\hline $2 \mathrm{SC}$ & $\begin{array}{l}\text { Birth of two healthy } \\
\text { children }\end{array}$ & $\begin{array}{l}\text { Hodgkin lym- } \\
\text { phoma Stage IIIB, } \\
8 \times \text { BEACOPP esc }\end{array}$ & + & + & $21(28)$ & 7 & No utilisation of tissue \\
\hline $3 \mathrm{BA}$ & $\begin{array}{l}\text { Birth of a healthy } \\
\text { child }\end{array}$ & $\begin{array}{l}\text { NHL CHOP, Rituxi- } \\
\text { mab }\end{array}$ & - & + & $28(36)$ & 8 & - \\
\hline $4 \mathrm{BM}$ & $\begin{array}{l}\text { Birth of a healthy } \\
\text { child }\end{array}$ & $\begin{array}{r}\text { Hodgkin lymphoma } \\
\text { stage IB, } 2 \text { ABVD }\end{array}$ & - & + & $24(30)$ & 6 & - \\
\hline $5 \mathrm{PL}$ & Pregnant & $\begin{array}{l}\text { Hodgkin lym- } \\
\text { phoma stage } 2 \mathrm{~A}, \\
4 \times \mathrm{ABVD}\end{array}$ & + & + & $20(27)$ & 7 & No utilisation of tissue \\
\hline $6 \mathrm{BB}$ & Pregnant & $\begin{array}{l}\text { Osteosarcoma, } \\
7 \times \text { VIDE }\end{array}$ & + & + & $21(27)$ & 6 & No utilisation of tissue \\
\hline 7 FK & Pregnant & $\begin{array}{l}\text { Hodgkin lymphoma } \\
\text { stage III, } 6 \times \text { BEA- } \\
\text { COPP }\end{array}$ & + & - & $29(32)$ & 3 & No utilisation of tissue \\
\hline $8 \mathrm{GU}$ & Pregnant & $\begin{array}{c}\text { Breast cancer (pT1c, } \\
\text { pN0, pM0, V0, L0, } \\
\text { G3, E and P posi- } \\
\text { tive, Her2neu neg. } \\
4 \times \text { EC, Taxotere) }\end{array}$ & + & + & $27(34)$ & 7 & No utilisation of tissue \\
\hline
\end{tabular}

EC Epirubicin Cyclophosphamid; BEACOPP esc Bleomycin, Etoposid, Adriamycin, Cyclophosphamide, Oncovin, Procarbazine, Prednisone in dose-escalation; NHL nonHodgkin-Lymphoma; $C H O P$ Cyclophosphamide, Hydroxydaunorubicin, Oncovin, Prednisone; $A B V D$ Adriamycine, Bleomycin, Vinblastine, Dacarbazine; VIDE Vincristine, Ifosfamide, Doxorubicin, Etoposide

All women without a wish to conceive were explicitly asked in the questionnaire to explain possible influences on their family planning. Their reasons for not wishing to conceive at the time of the questionnaire were as follows: no partnership $(n=7)$, homosexual partnership and no existing sperm donor $(n=2)$, fear of relapse of the disease $(n=5)$, and fear of having a child with impairments $(n=6)$. Eight women stated that they no longer wanted to conceive (11\%); of these, four women already had children and had completed their family planning. One woman had nine miscarriages and no live birth.

The women were asked about their opinions on the counselling for fertility preservation at the time of diagnosis (Fig. 3a, b). Eighty-six percent of them would recommend the counselling to other women in similar situations.
Fig. 3 a Do you feel that the counselling for fertility preservation was helpfull at the time of diagnosis? Number of answers $(n=72)$. b Was it the first time you learned about the side effect of infertility due to anticancer treatment during the fertility counselling? Number of answers $(n=72)$ a

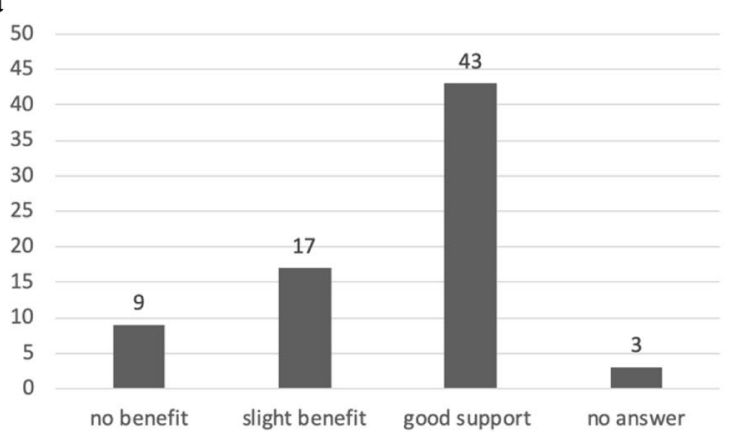

b

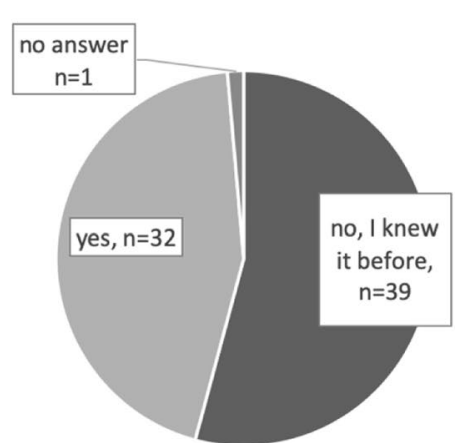




\section{Second follow-up interview by telephone, on average 6.0 years after diagnosis}

In April 2019, 59/72 women were reached by telephone for a follow-up interview. The mean age of the women at this time was $32.9 \pm 6.5(21-46)$ years. Of these, 17 women did not use a fertility preservation method at the time of first counselling (28.8\%). $N=33 / 59(56.0 \%)$ had undergone ovarian cryopreservation and $N=33 / 59(56.0 \%)$ had used the medical treatment with GnRH agonists; $19 / 59$ (32.2\%) used both methods of fertility preservation.

The fertility history of the women is shown in Fig. 4. In the interview, the women were explicitly asked about an ongoing or recurrent oncological treatment; $16 / 59$ (27\%) had anticancer treatment and, for medical reasons, were not permitted to become pregnant. 23/59 women (39\%) said that they had amenorrhea or hormonal replacement therapy after premature ovarian insufficiency. Of 55 women who were not pregnant at the time of the interview, 28 described their cycle as regular and four as irregular. Sixteen of the women used contraceptive methods.

$53 / 59$ women rated their overall health as 'good' or 'very good' $(90 \%)$ even with ongoing treatment. Twelve women had given birth to 16 healthy children until the time of the second counselling, and four women were pregnant at the time of the interview. None of the pregnant women had used their cryopreserved ovarian tissue. All pregnancies occurred spontaneously $(n=12,2 \%)$. Six women said that they were planning to become pregnant $(10 \%)$.

In the telephone interview, the patients expressed conflicting interests concerning their family planning. On one side, women described personal and medical situations which make pregnancies possible: 'I am in very good health' $(n=46)$, 'I live in a stable partnership' $(n=44)$, and 'I have a regular menstrual cycle' $(n=28)$.

On the other hand, aspects which do not allow a pregnancy were clearly stated: 'The disease makes a pregnancy impossible' $(n=16)$, 'No pregnancy because no stable partnership' ( $n=15)$, 'I have no ovulation anymore' $(n=23)$, and 'I use contraceptive methods' $(n=16)$.

Of the 33 women, who had ovarian tissue stored at the time of the interviewed 6 years after diagnosis, five (15\%) had already decided to dispose of their tissue. Three women chose to dispose of the ovarian tissue, because they had already completed their family planning, one woman because of her age (44 years), and one woman with bone metastasis because of her prognosis. One woman aged 39 years used the ovarian tissue and had two trials of intracytoplasmic sperm injection because of infertility of her partner; however, no pregnancy occurred. 27 of 33 women with a mean age of 30.3 years still had their ovarian tissue cryopreserved; of these, six women had active cancer disease, and six stated that their family planning had been completed. Sixteen women with stored ovarian tissue planned to conceive in the future.

Women expressed emotional reasons to further preserve the stored ovarian tissue in the telephone interviews. Examples are: one 35-year-old woman with liver and brain metastases after primary diagnosis of breast cancer said: 'Still, I really want to keep the tissue cryopreserved-I cannot throw away a part of my body.' Other women claimed the following reasons for ongoing cryopreservation: 'The knowledge that there is still some ovarian tissue makes a big difference for me', 'The tissue gives me a reassuring positive feeling', 'It is important for my psychological stability', and 'I like the thought that I could use the tissue for hormonal treatment—if necessary'.
Fig. 4 Flowchart showing fertility history 6 years after diagnosis of cancer $(n=59)$

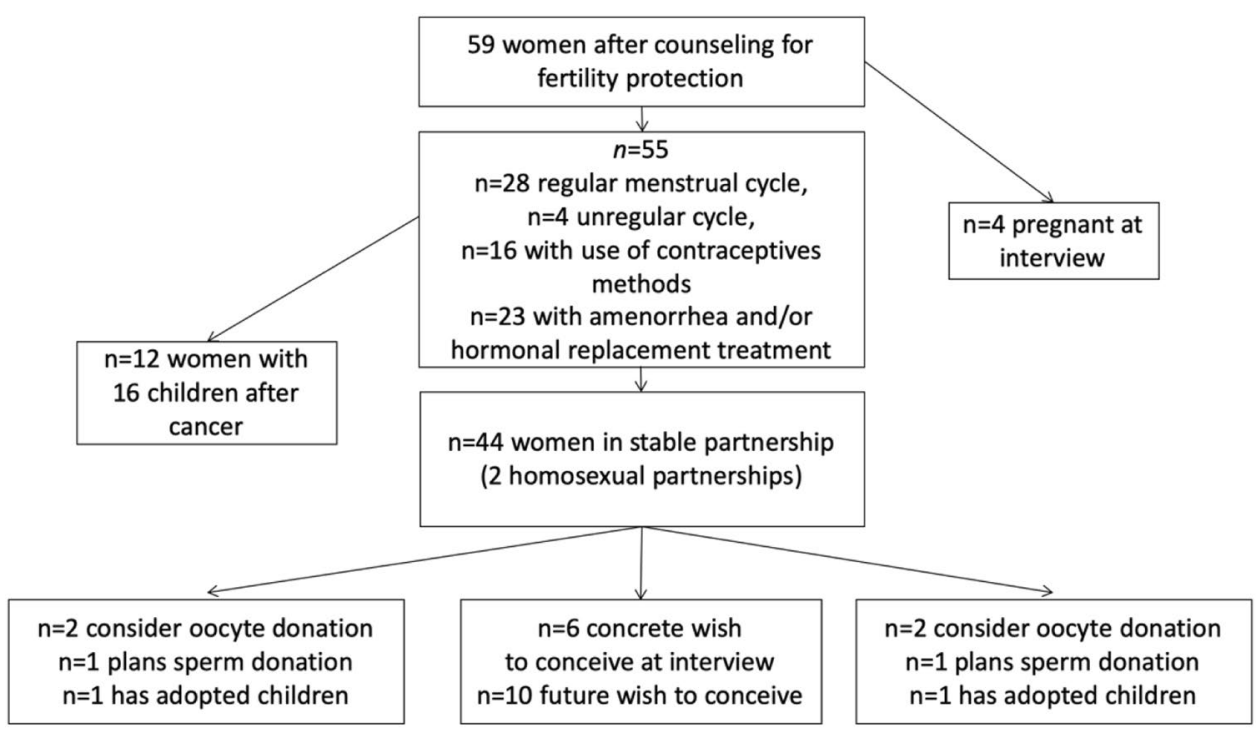




\section{Discussion}

Many women today have the opportunity to plan a family after surviving their cancer, as modern individual anticancer treatments have led to high survival rates in young cancer patients. Counselling regarding fertility preservation techniques at the time of diagnosis before initiating gonadotoxic treatment became a standard procedure. Nevertheless, follow-up data after counselling for fertility preservation are still sparse.

We present a follow-up study after fertility preservation counselling in a single university fertility centre. Fifty percent of the women who participated in the questionnaire study had ovarian tissue cryopreserved after the fertility preservation counselling. None of the women, which answered the questionnaire, had performed ovarian stimulation for cryopreservation of oocytes or embryos in our centre.

Although our data show that a high percentage of women with spontaneous pregnancies used GnRH agonists, this cannot be interpreted as an effect of ovarian suppression at the time of chemotherapy. The debate about the effect of $\mathrm{GnRH}$ agonists in protecting ovarian function against gonadotoxic treatment is still ongoing [9], and further prospective data are needed. Still, the data presented in this small study are reassuring. Even after the medical recommendation and individual decision to use fertility protection methods, spontaneous pregnancies can occur in a high percentage of women with unprotected sexual intercourse.

A current study from Sweden describes the long-term follow-up of 1254 girls and women after fertility preservation counselling in the period between 1998 and 2018 [8]. Women with benign and malignant diseases were counselled. In this study, the majority of women chose the cryopreservation of oocytes as their method of fertility preservation $(n=538,73 \%)$. This differs to the setting in the University Fertility Centre in Dresden, where hormonal stimulation and cryopreservation of oocytes or embryos were used only rarely, as the estimated costs for this treatment are about 3000-4000 Euros. These costs were required to be fully paid by the patients as the national health insurance did not cover the treatment during the study period. The latest political decision in Germany regarding the national health insurance to cover cryopreservation of gametes and ovarian tissue for fertility preservation reasons is likely to change the decisionmaking process.

The study by Rodriguez-Wallberg [8] showed that $27 \%$ $(n=255)$ of treated women with cancer returned to the fertility centre in Sweden for further diagnostic or therapeutic procedures. Twenty-six women conceived after using cryopreserved ovarian tissue or oocytes. The follow-up time of this study of about 3 years, as well as the percentage of breast cancer, corresponds to our data. The utilisation rates of cryopreserved embryos or oocytes of 8-29\% reported by Rodriguez-Wallberg [8] correspond to another European study, in which an utilisation rate of $24 \%$ is reported [10]. Interestingly, in this study with 137 women, who underwent hormonal stimulation for fertility preservation reasons between 2003 and 2016, a disposal rate of $12 \%$ without utilisation was described for cryopreserved embryos and oocytes in cancer patients. These data resemble the $15 \%$ disposal rate of ovarian tissue after 6 years of follow-up in our study (5/33 women). The main clinical difference between using oocytes or embryos and ovarian tissue is the severity of the intervention needed to conceive: In the former, a simple vaginal embryo transfer without risk of transplantation of tumour cells is needed, while the latter requires the laparoscopy and transplantation of autologous ovarian tissue with the theoretical risk of reintroducing tumour cells. Although the medical risks of surgery for removing and transplanting ovarian tissue by laparoscopy are considered low [11], the active decision for the right time to use the tissue and to plan the necessary surgery may be a barrier.

A prospective multicentre study with a cohort of almost 300 women with breast cancer and fertility-preservation methods has already published the baseline data, but not ongoing data of the reported usage of fertility-preservation methods [12]. In a study from Israel, 18/338 women used ovarian tissue for autotransplantation $(5.3 \%)$ after 6 years [13]. However, in the same study, a 30\% delivery rate was reported in 203 women without autotransplantation despite the fact that these women had ovarian tissue cryopreserved. These results correspond to our study: 9/32 women (28.1\%) became pregnant spontaneously without autotransplantation, even though they had tissue cryopreserved earlier. The cryopreserved ovarian tissue was used for autotransplantation in only 1 case out of 33 (3.0\%), without achieving a pregnancy.

Nevertheless, low utilisation rates of sperm frozen for fertility preservation in men with cancer have also been reported. In a retrospective study, the utilisation rate of cryopreserved sperm was analysed [14]. In a Scottish University Fertility Centre, 264 men with cancer banked sperm prior to chemotherapy or surgery between 2000 and 2017. After a follow-up of 4 years, only $5 \%$ of treated men returned to the centre to use their sperm for fertility treatment.

On average 6 years after being diagnosed with cancer, $16 / 33$ women still wish to use the ovarian tissue later. The positive psychological aspects of the cryopreserved ovarian tissue as a fertility reserve were clearly stated by the women. The follow-up period of a mean duration of 6 years in our study is, therefore, still not sufficient to describe the full effects of fertility preservation in young women. 


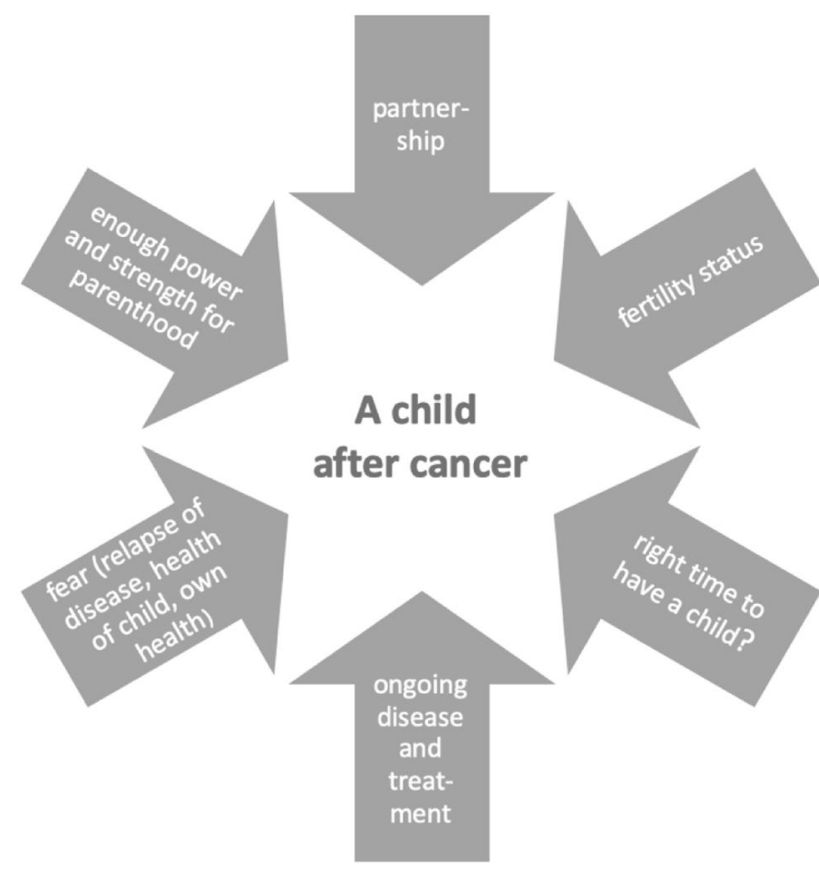

Fig. 5 Factors influencing the desire to have a child after cancer

Cryopreserved tissue, oocytes, or embryos make it possible to delay the chance of having children after cancer for several years ('frozen hope'). On one hand, our study showed a relatively high spontaneous pregnancy rate after cancer: $27.1 \%$ of women became pregnant spontaneously (16/59). On the other hand, however, the data indicate that the high rate of persistent amenorrhea of $39 \% 6$ years after treatment is a severe threat to fertility. At the time of the second follow-up, the women were on average 33 years old. These data must be interpreted carefully, as no endocrine follow-up was used to confirm this self-reported diagnosis.

A limitation of our study is the low response rate after 3 years of $51 \%$ in the written questionnaire study. Only women who decided to participate in the study could be followed for another 3 years for the second follow-up. This response rate can be explained through the exceptional and emotional situation of counselling on fertility preservation before gonadotoxic treatment. We do not have reliable data about the women who did not participate in our questionnaire study; a response bias by selective participation to the study cannot be ruled out.

The findings of the questionnaire study and the second follow-up by telephone interview of women diagnosed with cancer show that family planning after cancer is a complex construct. Many factors interfere in this decision (Fig. 5). Fertility preservation techniques increase the chance for a woman to have her own child after cancer, but several other factors may outweigh the biological effects. Studies to evaluate the effect of fertility-preservation methods must, therefore, be interpreted with care.

Acknowledgements Open Access funding provided by Projekt DEAL.

Author contributions The first draft of the manuscript was written by M. Goeckenjan and all authors commented on previous versions of the manuscript. All authors read and approved the final manuscript. Conceptualization/methodology: M. Goeckenjan, A. Freis, K. Glaß, and A. Germeyer. Formal analysis and investigation: M. Goeckenjan, A. Freis, K. Glaß, J. Schaar, and S. Torka. Resources: I. Trinkaus and K. Glaß. Supervision: A. Germeyer and P. Wimberger.

\section{Compliance with ethical standards}

Conflict of interest Potential conflicts of interest: A. Germeyer-Director of the board of Fertiprotekt e.V. No potential conflicts of interest with direct of potential influence or bias on the work: M. Goeckenjan, A. Freis, K. Glaß, J. Schaar, I. Trinkaus, S. Torka, and P. Wimberger.

Ethical approval The study protocol was approved by the local ethics committee. All procedures performed in this study were in accordance with the ethical standards of the institutional research committee and with the 1964 Helsinki declaration and its later amendments or comparable ethical standards.

Informed consent Informed consent was obtained from all individual participants included in the study (EK 314072015).

Open Access This article is licensed under a Creative Commons Attribution 4.0 International License, which permits use, sharing, adaptation, distribution and reproduction in any medium or format, as long as you give appropriate credit to the original author(s) and the source, provide a link to the Creative Commons licence, and indicate if changes were made. The images or other third party material in this article are included in the article's Creative Commons licence, unless indicated otherwise in a credit line to the material. If material is not included in the article's Creative Commons licence and your intended use is not permitted by statutory regulation or exceeds the permitted use, you will need to obtain permission directly from the copyright holder. To view a copy of this licence, visit http://creativecommons.org/licenses/by/4.0/.

\section{References}

1. Website of the German network for fertility preservation. https:// fertiprotekt.com/fertiprotektnetwork. Accessed 18 Nov 2019

2. Von Wolff M, Dittrich R, Liebenthron J, Nawroth F, Schüring AN, Bruckner T, Germeyer A (2015) Fertility-preservation counseling and treatment for medical reasons: data from a multinational network of over 5000 women. Reprod Biomed Online. https://doi. org/10.1016/j.rbmo.2015.07.013

3. German guideline for fertility preservation for women with oncologic diseases. https://www.awmf.org/uploads/tx_szleitlini en/015-0821_S2k_Fertilitaetserhaltung-bei-onkologischen-Thera pien_2017-12.pdf. Accessed 18 Nov 2019

4. Schüring AN, Fehm T, Behringer K, Goeckenjan M, Wimberger P, Henes M, Henes J, Fey MF, von Wolff M (2018) Practical recommendations for fertility preservation in women by the FertiPROTEKT network Part I Indications for fertility preservation. Arch Gynecol Obstet. https://doi.org/10.1007/s00404-017-4594-3 
5. Boettcher B, Goeckenjan M (2018) In: Ethics and Oncology: New issues of therapy, treatment, care, and, research. Arnason, Bobbert (Ed). Freiburg, Verlag Karl Alber Ann Arbor, Michigan ProQuest

6. Müller A, Keller K, Wacker J, Dittrich R, Keck G, Montag M, Van der Ven H, Wachter D, Beckmann M, Distler W (2012) Retransplantation of cryopreserved ovarian tissue: the first live birth in Germany. Dtsch Arztebl Int. https://doi.org/10.3238/arzte bl.2012.0008

7. Beckmann MW, Lotz L, Toth B, Baston-Büst DM, Fehm T, Frambach T, Germeyer G, Goeckenjan M, Häberlin F, Henes M, Hirchenhain J, Hübner S, Korell M, Krüssel JS, Müller A, Reinsberg J, Schwab R, Seitz S, Sütterlin M, van der Ven H, van der Ven K, Winkler-Crepaz K, Wimberger P, von Wolff M, Liebenthron L, Dittrich R (2019) Concept paper on the technique of cryopreservation, removal and transplantation of ovarian tissue for fertility preservation. Geburtshilfe Frauenheilkd. https://doi. org/10.1055/a-0664-8619

8. Rodriguez-Wallberg KA, Marklund A, Lundberg F, Wikander I, Milenkovic M, Anstacio A, Sergouniotis F, Wanggren K, Ekengren J, Lind T, Borgström B (2019) A prospective study of women and girls undergoing fertility preservation due to oncologic and non-oncologic indications in Sweden-Trends in patients' choices and benefit of the chosen methods after long-term follow up. Acta Obstet Gynecol Scand. https://doi.org/10.1111/aogs.13559

9. Lambertini M, Moore HCF, Leonard RCF, Loibl S, Munster P, Bruzzone M, Boni L, Unger JM, Anderson RA, Mehta K, Minton S, Poggio F, Albain KS, Adamson DJA, Gerber B, Cripps A, Bertelli G, Seiler S, Ceppi M, Partridge AH, Del Mastro L (2018) Gonadotropin-releasing hormone agonists during chemotherapy for preservation of ovarian function and fertility in premenopausal patients with early breast cancer: a systematic review and metaanalysis of individual patient-level data. J Clin Oncol. https://doi. org/10.1200/JCO.2018.78.0858

10. Muteshi C, Child T, Ohuma E, Fatum M (2018) Ovarian response and follow-up outcomes in women diagnosed with cancer having fertility preservation: comparison of random start and early follicular phase stimulation - cohort study. Eur J Obstet Gynecol Reprod Biol. https://doi.org/10.1016/j.ejogrb.2018.09.007

11. Beckmann MW, Dittrich R, Lotz L, van der Ven K, van der Ven HH, Liebenthron J, Korrell M, Frambach T, Sütterlin M, Schwab R, Seitz S, Müller A, von Wolff M, Häberlin F, Henes M, Winkler-Crepaz K, Krüssel JS, Germey A, Toth B (2018) Fertility protection: complications of surgery and results of removal and transplantation of ovarian tissue. Reprod Biomed Online. https:// doi.org/10.1016/j.rbmo.2017.10.109

12. Ruggeri M, Pagan E, Bagnardi V, Bianco N, Gallerani E, Buser K, Gianni M, Giordano L, Rabaglio M, Freschi A, Cretella E, Clerico M, Farolfi A, Simoncini E, Ciccarese M, Rauch D, Ramell M, Glaus A, Berardi R, Pellanda AF, Ribi K, Gelber S, Partridge AH, Goldhirsch A, Pagani O (2019) Fertility concerns, preservation strategies and quality of life in young women with breast cancer: baseline results form an ongoing prospective cohort study in selected European Centers. Breast 47:85-92. https://doi. org/10.1016/j.breast.2019.07.001

13. Lantsberg D, Farhi A, Zaslavsky-Paltiel I, Silverman BG, LernerGeva L, Orvieto R (2019) Deliveries following fertility preservation by ovarian tissue cryopreservation without autotransplantation-what should be expected? J Assist Reprod Genet 36(2):335-340. https://doi.org/10.1007/s10815-018-1341-z

14. Chatterton F, Kay V (2018) An audit of Ninewells Hospital fertility preservation service. J Obstet Gynaecol. https://doi. org/10.1080/01443615.2018.1444396

Publisher's Note Springer Nature remains neutral with regard to jurisdictional claims in published maps and institutional affiliations. 